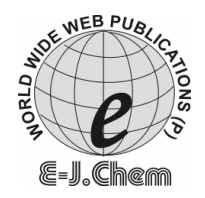

http://www.e-journals.net
ISSN: 0973-4945; CODEN ECJHAO

E-Journal of Chemistry 2009, 6(3), 909-914

\title{
Statistical Study on Physicochemical Characteristics of Groundwater in and around Namakkal, Tamilnadu, India
}

\author{
K. KARUNAKARAN*, P. THAMILARASU and R. SHARMILA \\ *Sona College of Technology, \\ Salem - 636 005, Tamilnadu, India. \\ Annai Mathammal Sheela Engineering College, Erumapatty, \\ Namakkal -637 013, Tamilnadu, India. \\ drkk@sonatech.ac.in
}

Received 18 December 2008; Accepted 6 March 2009

\begin{abstract}
Groundwater samples collected at different locations in and around Namakkal were analyzed for their physicochemical characteristics. Ten locations of groundwater samples were collected and studied for every two month for the period June-2007 to December-2007. The present investigation is focused on the determination of physicochemical parameters such as temperature, taste, turbidity, electrical conductivity, $\mathrm{pH}$, hardness, total solids, total dissolved solids, total suspended solids, chlorides, sulphate, nitrate, fluorides, dissolved oxygen, sodium, potassium and E.coli bacterium. Groundwater suitability for domestic and irrigation purposes was examined by using WHO and BIS standards, which indicate the groundwater in a few areas, were not much suitable for domestic and agriculture purposes. Thus the objective of this study is to identify the quality of groundwater especially in the town and near by town where groundwater is used for domestic and agriculture purposes is discussed.
\end{abstract}

Keywords: Groundwater, Drinking water quality parameters and Correlation analysis

\section{Introduction}

Groundwater is used for domestic, agriculture and industrial purpose in most parts of the world. Rural population living in India depends on groundwater for domestic and agriculture purpose. The major sources of water are rainfall, surface water involving rivers, lakes and groundwater involving wells and bore wells etc. Groundwater is the only alternative option even for the urban centers having well planned, designed and executed water supply systems 
like Namakkal town during the periods of water scarcity due to shortfall of rain or its nonoccurrence. Also normally the groundwater is the only water sources for the different locations, where the municipal water supply facilities are not made available. Nowadays, the groundwater potential and its quality level in major cities and urban centers is getting deteriorated due to the population explosion, urbanization, industrialization and the failure of monsoon and improper management of rain water. The groundwater quality is normally characterized by different physicochemical characteristics. These parameters change widely due to the various types of pollution, seasonal fluctuation, groundwater extraction, etc. Hence a continuous monitoring on groundwater becomes mandatory in order to minimize the groundwater pollution and have control on the pollution causing agents. Continuous monitoring on groundwater may become easier with the development of rapid water quality measurement techniques without making much compromise on the accuracy of measurement ${ }^{1-4}$. Namakkal District reveals that the very famous temple of Lord Anjenaya and Narashimar temple, Education city, Poultry and Egg city throughout India, Body builder of transport, Fort, tourist place and medical plants in Kollihills. The population of Namakkal District is around fourteen lakhs and area is 3363 Sq.km. Namakkal area comprises different types of archaean crystalline formations. The main water source for the town is from Caveri River which is situated about $20 \mathrm{~km}$ from the town. At present there is no major industry in and around the study area, yet household waste and garbage are directly discharged into the area. Keeping this in focus, the quality aspects of groundwater in Namakkal area were analysed for general water quality. Thus in this paper an attempt has been made to assess the physical and chemical properties of groundwater in and around Namakkal town.

\section{Experimental}

For the present study, the area in and around Namakkal town, Tamilandu was selected. From 10 locations the samples were collected. These were 1.Anbu nagar, 2.Thillaipuram, 3.Ganesapuram, 4. Nallipalayam, 5.S.K.Nagar, 6.Velagoundampatty, 7. Pudhanchanthai, 8.Valayapatty, 9.Aniyapuram and 10. Erumapatty. Overall, 30 samples i.e 3 samples from each location were collected, in which five locations from Namakkal town and remaining five locations are $10-15 \mathrm{~km}$ around Namakkal.

\section{Sample collection}

The sample selected areas are extensively used for drinking, household purposes and agricultural purposes were identified. The groundwater samples from the sampling locations were taken after operating the motor pumps for about 10 to $15 \mathrm{~min}$. Totally 30 samples were collected from ten locations using spot sampling procedure. The samples were collected in the pre-cleaned polythene bottles with necessary precautions.

\section{Analysis}

The temperatures of the samples were noted at their sampling point itself. The samples were put for examination in the laboratory to determine the physical, chemical and biological parameters. These include temperature, taste, turbidity, conductivity, $\mathrm{pH}$, hardness, total solids, total dissolved solids, total suspended solids, chlorides, sulphate, nitrate, fluorides, dissolved oxygen, sodium, potassium and heavy metals. Standard procedure involving spectrophotometry, flame photometry and volumetry were used for the experiment. Presumptive test using lactose bath was performed for drinking water samples to detect the presence of bacteria. The results were compared to WHO and BIS standards. 


\section{Results and Discussion}

All the collected water samples were mainly from bore well which were collected from bore well surrounded by plants, trees and houses. The physical, chemical and biological parameters are tabulated along with the standard values in Tables 1, 2 and 3.

Table 1. Physical parameters, in $\mathrm{mg} / \mathrm{L}$.

\begin{tabular}{lcccccccccc}
\hline Parameter & 1 & 2 & 3 & 4 & 5 & 6 & 7 & 8 & 9 & 10 \\
\hline Temp. ${ }^{\circ} \mathrm{C}$ & 32 & 31.5 & 32 & 30.5 & 29.8 & 29.7 & 29.6 & 30 & 30.1 & 30.0 \\
Colour & $\mathrm{cl}$ & $\mathrm{cl}$ & $\mathrm{cl}$ & $\mathrm{cl}$ & $\mathrm{cl}$ & $\mathrm{cl}$ & $\mathrm{cl}$ & $\mathrm{cl}$ & $\mathrm{cl}$ & $\mathrm{cl}$ \\
Odour & $\mathrm{ol}$ & $\mathrm{ol}$ & $\mathrm{ol}$ & $\mathrm{ol}$ & $\mathrm{ol}$ & $\mathrm{ol}$ & $\mathrm{ol}$ & $\mathrm{ol}$ & $\mathrm{ol}$ & $\mathrm{ol}$ \\
Taste & normal & salty & salty & normal & salty & sour & pleasant & sour & pleasant & normal \\
Turbidity & clear & clear & clear & clear & clear & clear & clear & clear & clear & clear \\
Conductivity & 3.57 & 4.52 & 1.79 & 2.52 & 2.51 & 2.21 & 2.63 & 2.10 & 1.26 & 1.26 \\
Total solids & 1560 & 2140 & 990 & 1430 & 920 & 1090 & 940 & 1400 & 890 & 650 \\
TDS & 1500 & 2070 & 950 & 1380 & 880 & 1050 & 920 & 1360 & 860 & 630 \\
TSS & 60 & 70 & 40 & 50 & 40 & 40 & 20 & 40 & 30 & 20 \\
\hline
\end{tabular}

cl-colourless; ol-odourless; TDS-Total Dissolved Solids; TSS - Total Suspended Solids.

\section{Colour, Odour, Taste, Turbidity and Temperature}

All the water samples were colorless, clear and odourless indicating the absence of colloidal substances, suspended and decomposed vegetation. Temperature is basically important for the chemical and biological reactions of organisms in water. The increase in temperature decreases the portability of water because at elevated temperature carbon dioxide and other volatile gases which impart taste are expelled. The temperature of the samples lies between 29 to $32{ }^{\circ} \mathrm{C}$ Table 1 .

\section{Conductivity and total solids}

Conductance of water samples varied from 1.26 to $4.52 \mathrm{mS} / \mathrm{cm}$. But samples 1 and 2 had relatively higher conductivity, which may be due to contamination of conducting material in water samples. According to BIS Standards, the acceptance limit for TDS in groundwater is $500 \mathrm{mg} / \mathrm{L}$, which may go up to $1500 \mathrm{mg} / \mathrm{L}$ in case of any alternative source. As per classification of TDS bore well water of Namakkal area come under moderately hard to harder especially sample code 1, 2, 4 and 8 exceeds for BIS permissible limit. Total solids include volatile and non-volatile solids. The presence of excessive solids in water indicates pollution which can lead to a laxative effect. The presence of excessive solids in water may be due to agricultural activities and geological parameters ${ }^{5}$.

\section{Discussion of chemical parameters}

The chemical parameters are tabulated in Table 2. The collected water samples have $\mathrm{pH}$ with in the permissible limits ranging from 6.90 to 8.33 . Total hardness of collected samples was found to be in the range from 380 to $1050 \mathrm{mg} / \mathrm{L}$. Total hardness values for samples 2, 4 and 8 are high due to the high concentration of calcium and magnesium salts. Hardness leads to heart diseases and kidney stone formation. These samples were not much suitable for drinking, washing, cleaning and laundering ${ }^{6}$. The chloride content of water samples collected lies in the range from 142 to $888 \mathrm{mg} / \mathrm{L}$. Sample 1, 2 and 4 have high concentration of chloride content and exceeds the permissible limit proposed by BIS and WHO. 
High chloride content in water bodies harms metallic pipes and structure as well as agricultural crops ${ }^{7}$. Total alkalinity of water samples collected lies in the range from 300 to $935 \mathrm{mg} / \mathrm{L}$. Sample 2 and 6 has high concentration of alkalinity and exceeds the permissible limit proposed by BIS. High alkalinity in water bodies leads to sour taste and salinity.

Table 2. Chemical and Biological parameters in $\mathrm{mg} / \mathrm{L}$.

\begin{tabular}{lcccccccccc}
\hline Parameter & 1 & 2 & 3 & 4 & 5 & 6 & 7 & 8 & 9 & 10 \\
\hline $\mathrm{pH}$ & 8.33 & 7.33 & 7.40 & 7.92 & 7.62 & 8.17 & 6.90 & 7.08 & 7.64 & 7.61 \\
Total hardness & 650 & 1050 & 830 & 860 & 810 & 400 & 805 & 880 & 380 & 475 \\
Total Alkalinity & 475 & 935 & 415 & 440 & 700 & 300 & 325 & 500 & 415 & 325 \\
Chloride & 692 & 888 & 266 & 479 & 284 & 178 & 437 & 316 & 149 & 142 \\
Sulphate & 240 & 220 & 150 & 230 & 150 & 110 & 92 & 87 & 85 & 70 \\
Nitrate & 50 & 30 & 25 & 55 & 34 & 30 & 25 & 25 & 23 & 25 \\
Sodium & 65 & 34 & 43 & 67 & 45 & 37 & 43 & 20 & 32 & 33 \\
Potassium & 30 & 25 & 12 & 23 & 11 & 10 & 13 & 15 & 16 & 12 \\
Iron & 0.5 & 0.4 & 0.3 & 0.4 & 0.1 & 0.2 & 0.1 & 0.2 & 0.1 & 0.1 \\
Chromium & 0.1 & 0.09 & 0.06 & 0.09 & 0.05 & 0.06 & 0.05 & 0.04 & 0.05 & 0.04 \\
Nickel & 0.04 & 0.03 & 0.01 & 0.04 & 0.01 & 0.02 & 0.01 & 0.01 & 0.02 & 0.01 \\
Lead & 0.1 & 0.08 & 0.06 & 0.1 & 0.05 & 0.06 & 0.05 & 0.04 & 0.03 & 0.05 \\
Fluoride & 1.3 & 1.2 & 0.4 & 1.4 & 0.5 & 0.1 & 0.3 & 0.5 & 0.6 & 0.2 \\
Dissolved oxygen & 5.30 & 5.25 & 7.12 & 5.23 & 6.11 & 3.10 & 7.13 & 7.15 & 7.16 & 7.12 \\
E.coli, counts/100 mL & 6 & 4 & 2 & 2 & 4 & 2 & 2 & 3 & 2 & 2 \\
\hline
\end{tabular}

Sulphates of water samples collected lies in the range from 70 to $240 \mathrm{mg} / \mathrm{L}$. Sample 1, 2 and 4 have moderately high values of sulphate and exceeds the permissible limit proposed by BIS and WHO. At concentrations of sulphate around $1000 \mathrm{mg} / \mathrm{L}$, it has laxative effect and causes gastro intestinal irritation ${ }^{8}$. Nitrate of water samples collected lies in the range from 23 to $55 \mathrm{mg} / \mathrm{L}$. Sample 1 and 4 has moderately high values of nitrate and exceeds the permissible limit proposed by BIS. High nitrate concentration in water bodies leads to organic pollution causes blue baby syndrome and it can be removed by desalination? Sodium of water samples collected lies in the range from 20 to $67 \mathrm{mg} / \mathrm{L}$. All the samples were with in the permissible limit proposed by BIS and WHO.

Potassium of water samples collected lies in the range from 10 to $30 \mathrm{mg} / \mathrm{L}$. Sample 1,2 and 4 have slightly high values of potassium and exceeds the permissible limit proposed by BIS. High potassium values may cause nervous and digestive disorder ${ }^{10}$. Iron, chromium, nickel and lead of water samples collected lies in the range from 0.1 to $0.5 \mathrm{mg} / \mathrm{L}, 0.04$ to $0.1 \mathrm{mg} / \mathrm{L}, 0.01$ to $0.04 \mathrm{mg} / \mathrm{L}$ and 0.03 to $0.1 \mathrm{mg} / \mathrm{L}$ respectively. Sample 1, 2 and 4 have slightly high values of these heavy metals and exceed the permissible limit proposed by BIS and WHO. High heavy metals concentration values may be causes Kidney damage, Carcinogenic, bone damage, nervous disorder and cancer $^{11}$.

Fluoride of water samples collected lies in the range from 0.1 to $1.4 \mathrm{mg} / \mathrm{L}$. Sample 1,2 and 4 have slightly high values of fluoride and exceeds the permissible limit proposed by BIS. High fluoride values may be causes fluorosis, which is characterized by mottling of teeth-enamel, nervous and skeletal disorder. Dissolved oxygen of water samples collected lies in the range from 3.10 to $7.16 \mathrm{mg} / \mathrm{L}$. Sample 1, 2 and 4 have slightly low values of dissolved oxygen and lower the permissible limit proposed by BIS. Low values may be affecting the fish life in aquatic system ${ }^{12}$. 
Table 3 and the above discussion show that some of the parameters have the concentration level greater than the permissible limit. The observed coefficient of variation for the parameters shows that the variations in the chlorides $(64.26 \%)$, iron $(62.5 \%)$, and fluoride $(72.31 \%)$ are of moderately high range. From this, it is concluded that various parameter concentrations are varying highly in different locations

Table 3. Statistical evaluation for different parameters in the bore well waters of in and around Namakkal District.

\begin{tabular}{llccccccc}
\hline S. No. & Parameter & Range & BIS & WHO & Mean & $\begin{array}{c}\text { Standard } \\
\text { deviation }\end{array}$ & $\begin{array}{c}\text { Standard } \\
\text { error }\end{array}$ & $\begin{array}{c}\text { Coefficient of } \\
\text { variation \% }\end{array}$ \\
\hline 1 & Temperature, ${ }^{\circ} \mathrm{C}$ & $29-32$ & $28-30$ & $28-30$ & 30.6 & 0.92 & 0.29 & 3.01 \\
2 & Conductivity & $1.79-4.52$ & 1.4 & 1.8 & 2.44 & 1.00 & 0.32 & 40.98 \\
& mS/cm & & & & & & & \\
3 & Total solids & $650-2140$ & 500 & 500 & 1221 & 435.49 & 137.81 & 35.66 \\
4 & $\mathrm{pH}$ & $6.9-8.33$ & $6.5-8.5$ & $6.5-9.5$ & 7.60 & 0.45 & 0.14 & 5.92 \\
5 & Total hardness & $380-1050$ & 500 & 500 & 714 & 227.09 & 71.86 & 31.80 \\
6 & Chlorides & $142-888$ & 250 & 250 & 383 & 246.19 & 77.91 & 64.26 \\
7 & Total alkalinity & $325-935$ & 200 & 250 & 513 & 248.88 & 78.76 & 48.51 \\
8 & Sulphate & $70-240$ & 200 & 200 & 143 & 65.42 & 20.70 & 45.62 \\
9 & Nitrate & $23-55$ & 45 & 45 & 35 & 12.99 & 4.11 & 36.90 \\
10 & Sodium & $32-67$ & 100 & 100 & 47 & 14.82 & 4.69 & 31.62 \\
11 & Potassium & $10-30$ & 10 & 10 & 17 & 6.86 & 2.17 & 40.04 \\
12 & Iron & $0.1-0.5$ & 0.3 & 0.3 & 0.26 & 0.15 & 0.05 & 57.69 \\
13 & Chromium & $0.04-0.1$ & 0.05 & 0.05 & 0.06 & 0.02 & 0.006 & 33.33 \\
14 & Nickel & $0.01-0.04$ & 0.01 & 0.01 & 0.02 & 0.01 & 0.003 & 50.00 \\
15 & Lead & $0.03-0.1$ & 0.05 & 0.05 & 0.05 & 0.03 & 0.009 & 60.00 \\
16 & Fluoride & $0.1-1.4$ & 1 & $1-1.5$ & 0.65 & 0.47 & 0.15 & 72.31 \\
17 & Dissolved & $3.10-7.16$ & 8 & 8 & 6.47 & 0.89 & 0.28 & 13.76 \\
& oxygen & & & & & & & \\
18 & E.coli.,counts/ & $2-6$ & 10 & 10 & 3 & 1.45 & 0.45 & 48.33 \\
& 100 mL & & & & & & & \\
\hline
\end{tabular}

Correlation is the mutual relationship between two variables. Direct correlation exists when increase or decrease in the value of one parameter is associated with a corresponding increase or decrease in the value of the other. The correlation is said to be positive when increase in one parameter causes the increase in the other parameter and it is negative when increase in one parameter causes the decrease in the other parameter. The correlation coefficient ( $r$ ) has a value between +1 and -1 . The correlation between the parameters is characterized as strong, when it is in the range of +0.8 to 1.0 and -0.8 to -1.0 , moderate when it is having value in the range of +0.5 to 0.8 and -0.5 to -0.8 , weak when it is in the range of +0.0 to 0.5 and -0.0 to $-0.5^{13}$.

The correlation coefficients (r) among various water quality parameters were calculated and the values of the correlation coefficients ( $r$ ) are given in Table 4. The strong positive correlation between sulphate and fluoride (-0.977), nitrate and fluoride (0.976), conductivity and chloride (0.954) were found. The correlation coefficients between conductivity and dissolved oxygen $(-0.777)$, total solids and fluoride $(0.754)$, total solids and sulphate $(0.732)$ were found to be moderate correlation. Sulphate and dissolved oxygen were found with negative correlation with other parameters. Total hardness, $\mathrm{pH}$, sodium, potassium and total alkalinity were showing weak correlation with the other parameters. 
Table 4. Correlation coefficient (r) for different parameters in the borewell waters collected from in and around Namakkal District.

\begin{tabular}{|c|c|c|c|c|c|c|c|c|c|c|c|}
\hline Parameters & $\mathrm{C}$ & TS & $\mathrm{pH}$ & TH & TA & $\mathrm{Cl}$ & $\mathrm{SO}_{4}$ & $\mathrm{NO}_{3}$ & $\mathrm{Na}$ & $\mathrm{K}$ & $\overline{\mathrm{DO}}$ \\
\hline Conductivity & 1.000 & & & & & & & & & & \\
\hline Total solids & 0.871 & 1.000 & & & & & & & & & \\
\hline $\mathrm{pH}$ & 0.067 & 0.066 & 1.000 & & & & & & & & \\
\hline Total hardness & 0.625 & 0.623 & -0.495 & 51.000 & & & & & & & \\
\hline Total alkalinity & 0.478 & 0.587 & 0.257 & 0.014 & 1.000 & & & & & & \\
\hline Chloride & 0.954 & 0.892 & 0.009 & 0.665 & 0.337 & 1.000 & & & & & \\
\hline Sulphate & 0.753 & 0.732 & 0.449 & 0.502 & 0.232 & 0.791 & 1.000 & & & & \\
\hline Nitrate & 0.282 & 0.472 & 0.262 & 0.354 & -0.024 & 0.336 & -0.91 & 41.000 & & & \\
\hline Sodium & 0.189 & 0.333 & 0.136 & 0.386 & -0.021 & 0.267 & -0.94 & 40.010 & 1.000 & & \\
\hline Potassium & 0.698 & 0.773 & 0.354 & 0.328 & 0.170 & 0.829 & $-0.81^{\prime}$ & 70.115 & 0.001 & 1.000 & \\
\hline Fluoride & 0.653 & 0.754 & 0.319 & 0.464 & 0.093 & 0.779 & -0.97 & 70.976 & 0.000 & 0.000 & 1.000 \\
\hline $\begin{array}{c}\text { Dissolved } \\
\text { oxygen }\end{array}$ & -0.777 & -0.735 & -0.409 & -0.486 & -0.192 & -0.808 & $3-0.94$ & $1-0.05$ & -0.04 & -0.005 & -0.0031 .00 \\
\hline
\end{tabular}

\section{Conclusion}

In the current study based on physicochemical parameters thus concluded that the sample location code $3,5,6,7,8,9$ and 10 these water parameters in the limits of BIS and WHO standards. Hence these sample water can be used for drinking, irrigation and fisheries. Water sample location code 1, 2 and 4 are moderately higher in Physical and Chemical parameters which may not be much fit for drinking, cooking purposes. In general this water may be boiling, cooled, filtered and used for drinking purposes. Based on physicochemical studies water collected from the distance of 10-15 Km from Namakkal town is much better than the Namakkal town waters. The statistical analysis of the experimentally estimated water quality parameters on water samples yielded the range of the variation, mean, standard deviation and co-efficient of variation. Since the correlation coefficient gives the interrelationship between the parameters, correlation coefficients were calculated. Results of correlation analysis show that sulphate and fluoride, nitrate and fluoride, conductivity and chloride are having high correlation with most of the other parameters.

\section{References}

1. Jain \& Jain, A text book of Engineering Chemistry, Dhanpat Rai \& Sons, New Delhi.

2. Water quality and Defloration Techniques, Rajiv Gandhi National Drinking Water Mission, Government of India, New Delhi, 1993.

3. De A K, Environmental Chemistry, $2^{\text {nd }}$ Ed., Wiley Eastern Publication, 1998.

4. Trivedy R K and Goel P K, Chemical and biological methods for water pollution studies, Environmental Publication, Karad, 1986.

5. $\quad$ Kasthuri R, et al., Indian J Environ Protect., 2005, 25(3), 245-248.

6. $\quad$ Lalitha S, et al., Indian J Environ Protect., 2004, 24(12), 925-930.

7. $\quad$ Suresh C, Tripathi B D and Mishra B P, Com Physico Eco., 1992, 17(3), 92-96.

8. Bhatia S C, Environmental Chemistry, CBS Publications, New Delhi, 2000.

9. Xanthoulis D and Wallender W W, Furrow infiltration and design with cannery wastewater, Trans ASAE, 1991, 34, 2390-2396.

10. Tiwari D R, Indian J Environ Health, 2001, 43(1), 176.

11. Gupta and Suruchi, Asian J Chem., 2001, 13(3), 16-17.

12. Siddiqui K A, Pollution conservation and forestry, $2^{\text {nd }}$ Ed., Kitab Mahal Publication, Allahabad, 2002.

13. Achuthan Nair, G Abdullan I Mohamad and Mahamoud Mahdy Fadiel., Poll Res., 2005, 24(1), 1-6. 


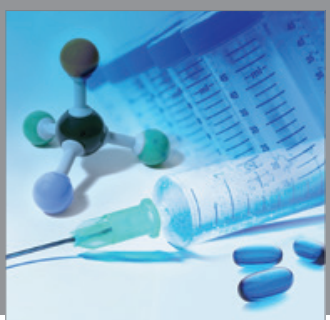

International Journal of

Medicinal Chemistry

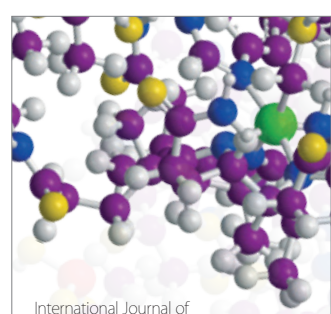

Carbohydrate Chemistry

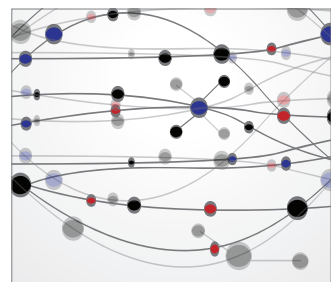

The Scientific World Journal
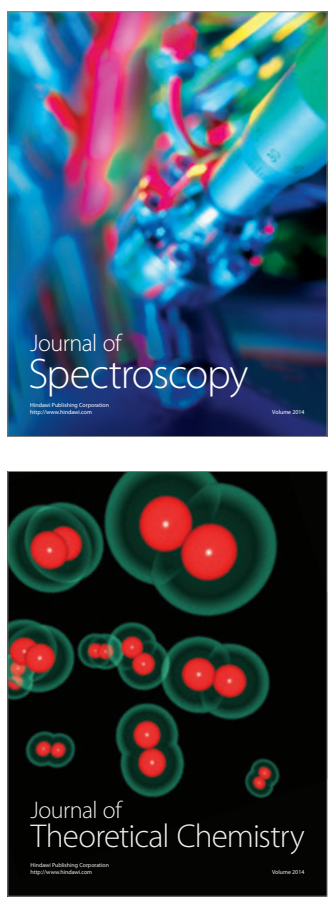
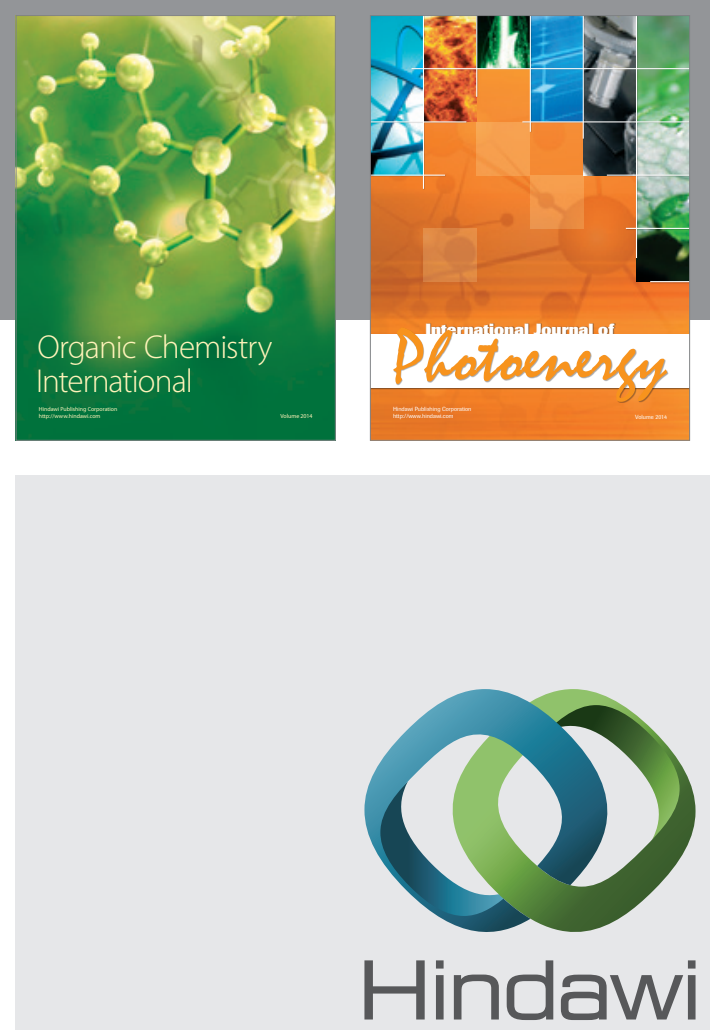

Submit your manuscripts at

http://www.hindawi.com
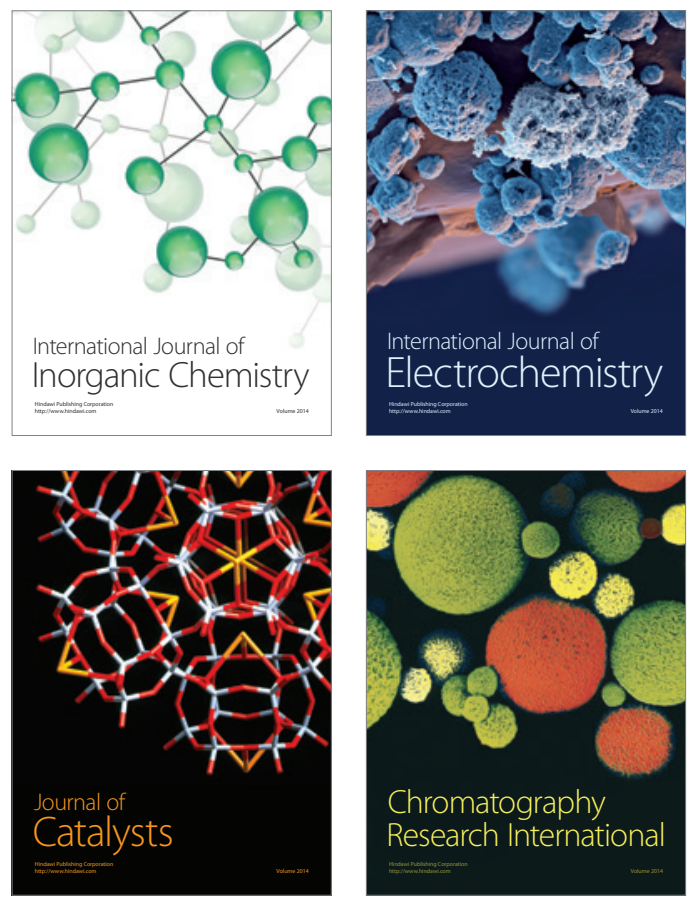
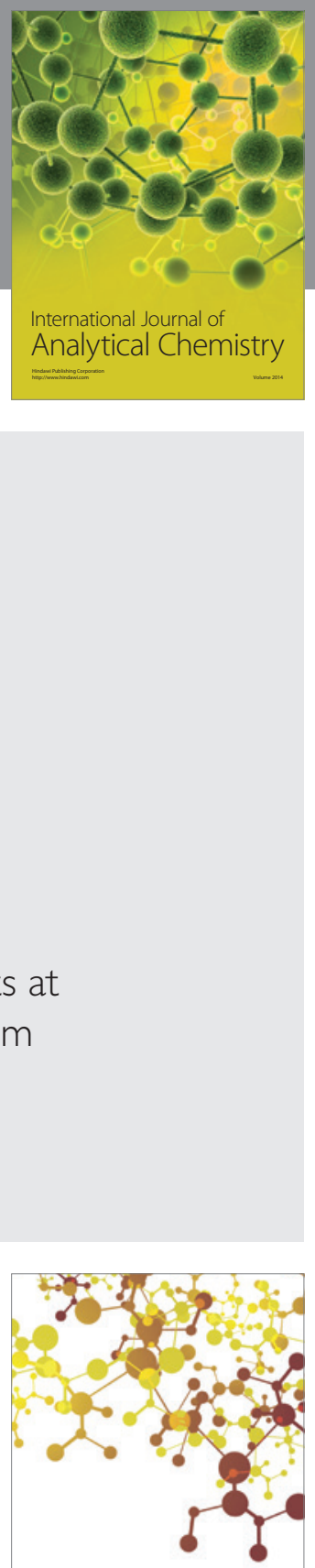

Journal of

Applied Chemistry
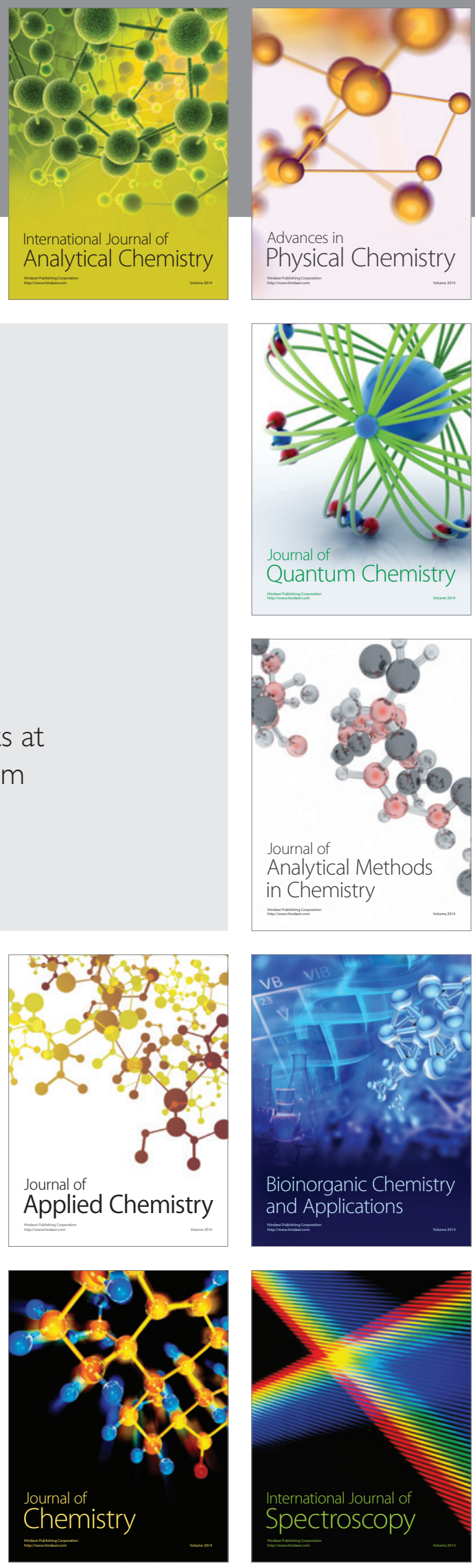